\title{
Mucolipidosis type II in a low birth weight preterm infant: A case report
}

\section{Düşük doğum ağırlıklı preterm bir infantta mukolipidozis tip II. Bir olgu sunumu}

\author{
Melis BİLEN ${ }^{1}$, Pınar ARICAN ${ }^{1}$, Dilek ÇAVUŞOĞLU ${ }^{2}$, Pınar GENÇPINAR ${ }^{1}$, Bumin Nuri DÜNDAR ${ }^{3}$, \\ Nihal OLGAÇ DÜNDAR ${ }^{2}$
}

${ }^{1}$ Tepecik Ĕ̆itim ve Araştırma Hastanesi, Çocuk Nöroloji Klini ği, İzmir

${ }^{2}$ İzmir Katip Çelebi Üniversitesi, Çocuk Nöroloji Bilim Dalı, İzmir

${ }^{3}$ İzmir Katip Çelebi Üniversitesi, Çocuk Endokrin ve Metabolizma Bilim Dalı, İzmir

\begin{abstract}
Mucolipidosis type II and III are autosomal recessive lysosomal storage disorders caused by the deficiency of the enzyme $\mathrm{N}$-acetylglucosamine-1-phosphotransferase. In this case report we present a preterm born infant with significant developmental delay, secundum atrial septal defect, central hypothyroidism, inguinal hernia, hearing loss and chronic bronchopulmonery disease. She was evaluated for metabolic disorders because of her psychomotor retardation and diagnosed with mucolipidosis type II. Mucolipidosis type II is a very rare metabolic disorder. The presenting symptoms are very much like mucopolisaccaridosis type I but it has an early onset and there is no mucopolysaccariduria. So we should think of mucolipidosis type II in a relatively younger patient with symptoms like mucopolisaccaridosis type I.
\end{abstract}

Keywords: Mucolipidosis, lysosomal storage disorders, preterm infant

$\ddot{0} \mathbf{z}$

Mukolipidozis tip II ve tip III, N-asetilglukozamin-1-fosfotransferaz enzim eksikliğinin neden olduğu otozomal resesif geçişli lizozomal depo hastalığıdır. Bu olgu bildiriminde, kronik bronkopulmoner hastalığı, işitme kaybı, sekundum atriyal septal defekti, santral hipotiroidisi ve belirgin gelişme geriliği olan preterm doğan bir infant sunulmuştur. Gelişim geriliği nedeni ile metabolik hastalıklar açısından değerlendirildi ve mukolipidozis tip II tanısı aldı. Mukolipidozis tip II çok ender görülen bir metabolik hastalıktır. Mukopolisakkaridoz tip I ile semptomları çok benzer fakat mukolipidozis tip IIerkenbaşlangıçıdırvemukopolisakkaridürisaptanmaz. Mukopolisakkaridoz tip I ile benzer semptomları olan yaşı daha küçük hastalarda mukolipidozis tip II tanısı aklımıza gelmelidir.

Anahtar kelimeler: Mukolipidozis, lizozomal depo hastalığı, preterm infant

Alındığı tarih: 12.12.2016

Kabul tarihi: 25.06 .2017

Yazışma adresi: Doç. Dr. Nihal Olgaç Dündar, Güney Mahallesi 1140/1 Sokak No:1, Yenișehir, Konak - İzmir / Türkiye

e-mail: nodundar@gmail.com

\section{INTRODUCTION}

Mucolipidosis type II (I-cell disease) and mucolipidosis type III (pseudohurler polydistrophy) are autosomal recessive lysosomal storage disorders. Their phenotypical features resemble mucopolysaccaridosis type I (Hurler disease), but the onset is earlier and there is no evidence of mucopolysaccariduria ${ }^{(1,2)}$.
Mucolipidosis type II is caused by a defect in proper lysosomal enzyme phosphorylation and localization, which results in accumulation of lysosomal substrates. It is phenotypically more severe than the allelic disorder mucolipidosis type III. Mucolipidosis III produces less severe symptoms and progresses more slowly ${ }^{(3,4)}$.

The clinical features include small or low- 
birthweight infant for its gestational age, coarse facial features, craniofacial abnormalities, restricted joint movements, skeletal abnormalities (clubfoot, thoracic deformity including kyphosis, dislocation of the hips, deformed long bones), physchomotor retardation, generalized hypotonia, inguinal hernia, and gingival hypertrophy ${ }^{(5,6)}$. ML II alpha/beta is caused by a homozygous or compound heterozygous mutation of the GNPTAB gene. This gene is located on chromosome 12 at $12 \mathrm{q} 23.2^{(7)}$. Mutations in GNPTAB result in a deficiency in N-acetylglucosamine-1phosphotransferase (GlcNAc-1-phosphotransferase). This deficiency results in improper lysosomal enzyme phosphorylation, causing an accumulation of lysosomal substrates in several organs and tissues, specifically in the skeletal system ${ }^{(8)}$. In this case report we present a preterm newborn diagnosed with mucolipidosis type II.

\section{CASE REPORT}

A 4- month- old female patient was admitted to hospital with chronic bronchopulmonary disease. She was born by cesarean section at 34 weeks of gestation after a normal pregnancy. Her birth weight was 1140 gr which showed intrauterine growth retardation. Her parents were relatives. The mother was 28 years, and the father was 31 years old and both of them were healthy. Two siblings aged 6 and 3 years were healthy. In the family history the mother's cousins passed at early age because of an unknown reason.

On physical examination, she appeared dysmorp-

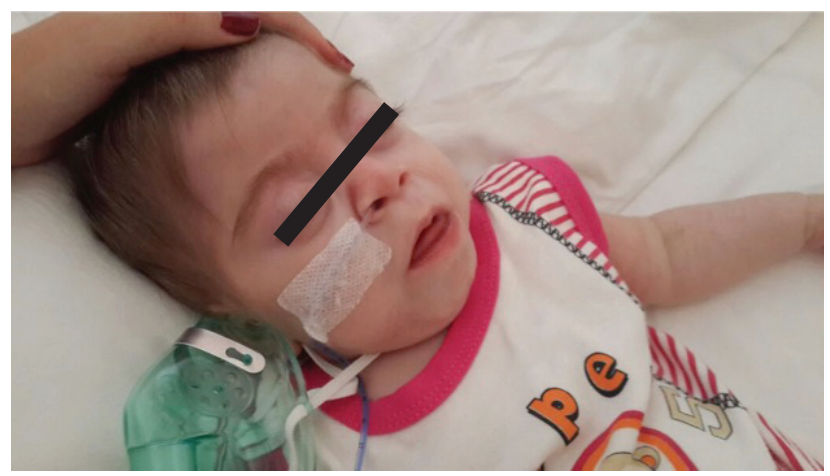

Figure 1. Coarse facial features. hic, with coarse facial features, including a flat face, depressed nasal bridge, micrognathia, protruded round eyes and enlarged tongue (Figure 1). She had left inguinal hernia, significant global developmental delay and generalized muscular hypotonia.

At birth the infant had respiratory problems so she was intubated and admitted to the intensive care unit. She was ventilator- dependent and extubation failed several times. She stayed at intensive care unit for 76 days. After being discharged she had several hospital admissions because of pnemoniae and sepsis. Because of motor and mental retardation she was evaluated for genetic, and metabolic disorders.

Her thyroid-stimulating hormone levels were high so she was diagnosed with central hypothyroidism and received levothyroxin treatment. She was evaluated for cardiac disorders using transthoracic echocardiography. Echocardiogram demonstrated a secundum atrial septal defect. Her ophtalmologic examination was normal. Her hearing tests showed hearing loss. Tandem mass spectrometric findings were within normal limits. X-ray surveys of the patient didn't show any skeletal anomalies.

Urine tests were performed in search for oligosaccarides, sialic acid and mucopolisaccarides. Trace dermatan sulphate was seen in the urine samples. To confirm the diagnosis of metabolic disorders, former enzymatic tests were performed. Plasma beta - hexosaminidase $\mathrm{A}+\mathrm{B}$ and alpha-mannosidase levels showed consistency with mucolipidosis type II-III (Beta - hexosaminidase A+B: 22641 umol/l/h, alphamannosidase: $5011 \mathrm{umol} / \mathrm{1} / \mathrm{h}$ ) and she was diagnosed with mucolipidosis type II. Genetic tests were not applied in this patient.

\section{DISCUSSION}

We present this case, because it is a very rare disorder and it resembles mucopolysaccaridosis type I, but with an early onset. To our knowledge, this is the first case report of mucolipidosis type II in a preterm infant.

Mucolipidosis type II and mucolipidosis type III 
are rare disorders. They have an early onset compared to mucopolysaccaridosis. Various lysosomal enzyme activities can be measured in serum and in cultured fibroblasts for diagnosis. The activities of betahexosaminidase, iduronate sulfatase, and arylsulfatase A are deficient in cultured fibroblasts, but their serum levels are 10-20 times higher than their reference ranges ${ }^{(2,3)}$.

Our patient was a preterm newborn with severe respiratory problems and severe developmental and growth delay. She had several hospital admissions because of sepsis and pneumonia. She had coarse facial features, inguinal hernia, hypotonia and secundum atrial septal defect as well. Cardiac manifestations reported in the published reports include cardiomyopathy, right and generalized ventricular hypertrophy, valvular thickening and mitral valve regurgitation were the most frequent findings ${ }^{(9)}$. In patients with mucolipidosis type II ocular findings such as corneal clouding, retinopathy and astigmatism may be seen, but our patient's ophtalmological examination was normal.

We suspected mucopolisaccaridosis due to the clinical features. Urinalysis showed trace dermatan sulphate levels, and also enzymatic tests were performed. Beta-hexosaminidase $\mathrm{A}+\mathrm{B}$ and alphamannosidase levels showed consistency with mucolipidosis type II-III.

Mucolipidosis II appears to differ radiologically early on from the other mucolipidoses and mucopolysaccharidoses. Talocalcaneal stippling, sacrococcygeal sclerosis, severe generalized vertebral body sclerosis, vertebral body rounding of the lower thoracic/lumbar spine and rickets/hyperparathyroidism - like changes in the early years of life strongly suggest the diagnosis of mucolipidosis II. Periostal cloaking (outline of periostal margins), is observed around the diaphyses of the large long bones and this transient phenomenon is rarely detectable after the first year of life ${ }^{(10)}$. We performed radiological surveys of our patient and no radiologic anomalies were detected.

The diagnosis of mucolipidosis type II/III is based on clinical, radiological, biochemical and molecular findings. A mutation study of GNPTAB is important in terms of confirmation of the disease and prediction of prognosis. Genotypes with compound heterozygotes consisting of nonsense and frameshift mutations are not expected to produce RNA product, and they are associated with a more severe phenotype ${ }^{(11)}$. In our case we couldn't perform any molecular and genetic tests to the patient. A mutation study gives important information about the prognosis and helps to confirm the diagnosis.

The prognosis of mucolipidosis is poor and it usually has a fatal outcome. Most patients die because of cardiorespiratory insufficiency in early childhood. Treatment is usually symptomatic and supportive. Bone marrow transplantation or hematopoietic stem cell transplantation has been attempted in some children but the information on their outcomes is not yet available ${ }^{(12)}$.

A patient with coarse facial fetaures, dysmorphic phenotypical features and frequent respiratory tract infections should remind us metabolic disorders. Mucolipidosis type II is a very rare metabolic disorder and the symptoms are very much like mucopolisaccaridosis type I but it has an early onset and there is no mucopolysaccariduria. So we should think of mucolipidosis type II in a relatively younger patient with symptoms like mucopolisaccaridosis type I.

Informed Consent: Written informed consent was obtained from patient's parent.

Conflict of Interest: No conflict of interest was declared by the authors.

Financial Disclosure: The authors declared that this study has received no financial support.

\section{REFERENCES}

1. Alfadhel M, AlShehhi W, Alshaalan H, Al Balwi M, Eyaida W. Mucolipidosis II: first report from Saudi Arabia. Ann Saudi Med 2013;33(4):382-386. https://doi.org/10.5144/0256-4947.2013.382

2. Paik KH, Song SM, Ki CS, Yu HW, Kim JS, Min KH, et al. Identification of mutations in the GnPTA (MGC4170) gene coding for GlcnAc-phosphotransferase alpha/beta subunits in 
Korean patients with mucolipidosis type II or type IIIA. Human Mutation 2005;26(4):308-314. https://doi.org/10.1002/humu.20205

3. Cathey SS, Leroy JG, Wood T, Eaves K, Simensen RJ, Kudo $\mathrm{M}$, et al. Phenotype and genotype in mucolipidoses II and III alpha/beta: a study of 61 probands. Journal of Medical Genetics 2010;47(1):38-48.

https://doi.org/10.1136/jmg.2009.067736

4. Kovacevic A, Schranz D, Meissner T, Pillekamp F, Schmidt KG. Mucolipidosis II complicated by severe pulmonary hypertension. Molecular Genetics and Metabolism 2011;104(1-2):192-193. https://doi.org/10.1016/j.ymgme.2011.06.026

5. Coutinho MF, da Silva Santos L, Girisha KM, Satyamoorthy K, Lacerda L, Prata M et al. Mucolipidosis type II alpha/beta with a homozygous missense mutation in the GnPTAb gene. American journal of medical genetics. Part $A$ 2012;158A(5):1225-1228. https://doi.org/10.1002/ajmg.a.35295

6. Tylki-Szymańska A, Czartoryska B, Groener JE, Ługowska A. Clinical variability in mucolipidosis III (Pseudo-Hurler polydystrophy). Am J Med Genet 2002;108:214-218. https://doi.org/10.1002/ajmg.10224

7. Tiede S, Storch S, Lu€bke T, Henrissat B, Bargal R, RaasRothschild A, et al. Mucolipidosis II is caused by mutations in GNPTA encoding the alpha/beta GlcNAc-1 phosphotransferase. Nat Med 2005;11:1109-1112. https://doi.org/10.1038/nm1305

8. Kudo M, Brem MS, and Canfield WM. Mucolipidosis II (I-cell disease) and mucolipidosis IIIA (classical pseudohurler polydystrophy) are caused by mutations in the GlcNAcphosphotransferase alpha/beta - subunits precursor gene. Am J Hum Genet 2006;78:451-463. https://doi.org/10.1086/500849

9. Okada S, Owada M, Sakiyama T, Yutaka T, Ogawa M. I-cell disease: clinical studies of 21 Japanese cases. Clinical Genetics 1985;28(3):207-215. https://doi.org/10.1111/j.1399-0004.1985.tb00388.x

10. Lai LM, Lachman RS. Early characteristic radiographic changes in mucolipidosis II. Pediatric Radiology 2016;46(12):1713-1720. https://doi.org/10.1007/s00247-016-3673-0

11. Yang M, Cho SY, Park HD, Choi R, Kim YE, Kim J, \& Song J. Clinical, biochemical and molecular characterization of Korean patients with mucolipidosis II/III and successful prenatal diagnosis. Orphanet Journal of Rare Diseases 2017;12(1):11. https://doi.org/10.1186/s13023-016-0556-2

12. Leroy JG, Cathey S, \& Friez MJ. Mucolipidosis II. 2012. 